\title{
付 録
}

6 月 8 日の共通論題の報告予定者であった奥田央氏 (東大, 非会員) が長期在外研究 (ソ連)に急き ょ出発されたため，当日の同氏の報告はなかったが，同氏のど同意をえて，第 24 回大会報告要旨集の 一部分をとこに転載します。

\section{ソ連小工業史研究の意義について}

奥 田央 (東大)

研究史上，ソ連小工業史とは，帝政期にレーニンが工業における資本主義発展の母体としてとらえた ところのいわゆるクスターリ工業の革命後の歴史過程を主として意味している(まとまったものとして， たとえば,ア・イ・ブズラーエワ『ソ連小工業協同化のレーニン主義的計画』, モスクワ, 1969 年 など）。クスターリ工業の圧倒的多数が農民の副業的な営業であったかぎりにおいて，ソ連小工業史は 本質的には農業・農民史の一部を構成している。

ての問題はなによりもまず歴史家の研究領域である。そのととを明瞭に示すためには，次の 2 つの史 実をあげるだけで十分であろう。農民の工業は，戦時共産主義期の政策的ジグザグを経て，1921 年 以降, ソヴェト政権の本格的な㩁護の対象とされ，農業・農民経営の復興という観点から好ましい役割 を演じるものとして位置づりられていた。20 年代中頃には, およそ 10 経営に 1 経営の農民経営がて のような工業的活動に従事していたと見皘るてとができる。

しかし，未曾有の工業化と集団化を遂行したソヴェト第一次 5 カ年計画のあと，1934 年 7 月に中 央委員会によって招集された集団化に関する特別会議において,ヴァレイキス（中央黒土州党委員会書 記 ）によって，すべてのコルホーズにクスターリ経営をつくりだすととを「訴可する」ための提案がな された (『ソ連邦共産党史の諸問題』，1982 年, 第8号, 52 頁)。もとよりこの提案は, 当時の 現実のなかでそれが「禁止されていた」ととを間接的に証明するすのである。こうして歴史研究にとっ ては，20 年代から 30 年代にかけて農民の工業経営をめぐって何が起てったのかが当然の関心事とな る。

1920 年代の後半にすでに, 小工業の縮小がはじまっていたてとは,「労働週数」（生産従事者に 就業時間（週）を乗じた数字）の計測をおとなったゴスプランの統計にはっきりと記録されている(『手 工業協同組合通報」，1931 年, 第 8 号, 4 頁)。その主要な原因は, 原料調羍をめぐる国営大工業 と農民の工業との関係の尖鋭化, それを背景とした後者の活動への規制であり, それは構造的には, 農 民内市場の抑制と農村外般出の強化という当時の一般的㑯向と軌を一にしている。調達危機をきっかけ とした農村市場の閉鎖という「非常措置」はそれをドラスティックに象徽したものである。てれはそれ 自体としてソヴェトの都市集中的な工業化の論理的な帰結であるが, さらにその系として, 急テンポの 工業化の使命を負った国営工業による小工業の直接的な国有化という事実も, 20 年代末から 30 年代 を通して傾向的に看取するととができる。しかしながら一層興味深いてとは，さきのヴァレイキスの提 案からもうかがうととができるように，工業化と並行して進行した集団化（コルホーズ建設）が農民の 工業にいかなるインパクトをあたえたかという問題である。

集団化の進展とともに農民の工業に著しい縮小がおとったととは疑う余地がない。それはとくに1929年 
末から翌年春にかけての集団化の「いきすぎ」の時期に頂点に達した。著しい縮小をとうむったのは， 私的な経営だけではなかった。多くの工業村落を把挃していた手工業協同組合一それはレーニンの共 同組合計画の正当な嫡子とみなされていた—も大量に解散された（この問題は，同じ時期に農業協同 組合の一次細胞が大量に崩壊し，協同組合を媒介せずに私的な農民が「直接的に」コルホーズへ移行し たとととも関連しており，一層の研究が要求されている）。クスターリをふくむ非農業的活動に従事す るものは, 農業以外からの所得の存在, それによる農業経営に対する相対的な無関心のゆ元に，一般の 農民以上に農業集団化には総して敵対的であった。したがってての「いきすき」の時期にはクスターリ を無理矢理に農作業へ投入するという事態が㕕範に発生した。さらに他面では，30年代をとおしてか つてのクスターリが営業を捨てて国営工業の労㗢者へ転化するという過程がみられた。との両過程を, 私は，農業と工業への一種の両極分解の過程とみたととがある( 批著『ソヴェト経济政策史』, 東京大 学出版会, 1979 年, 第 4 章)。

それまで農村の (そして一部は都市の) 工業製品に対する多様な需要にとってはとんど排他的に重要 な役割を演じていた農民の工業がての時期に急激な縮小をとうむったてとてそが，1930 年代を特徴 づける猛烈な大衆消費財不足の直接的な原因であった。1931 年にはすでに，消費財不足の根本的な 原因は「無限の数の営業が現在消滅しつつあるてとにある」と断定がくわえられた（新聞「クスターリ とアルテリ」1931年5月24日号)。多椂な消費財を入手するために労㗢者も農民も多大の時間を 空費し，そのととは生産的労㗢そのものに打撃をくわえた。

さきにみたように，第一次 5 力年計画期における農民の工業の急激な縮小は, 農業生産強化の要求を ともなった集団化, および労働者の補充と原料調達の強化を求める工業化という当時の 2 つの不動の政 策と本質的に結合していた。したがって，それまでの擁謢政策がなおも維持されているてとを双ってソ ヴェト政権が事態の修正をくりかえして要求したてとはほとんど央効をもちえなかった。むしろ, 当時 のトップの指導者のなかでは，ての「両極分解」をソヴェト経済建設の必要条件とみなし，30 年代初 頭の「いきすき」をデ・ファクトに容認しようとする隠された見解があったとみるととさえ可能である。 興味深い一例をあげよう。さきに言及した 1934 年7月のヴァレイキスによる提案について,スター リンは次の上うな理由からそれを斥けた。コルホーズにおいてクスターリ経営を発展させると，第1に, 都市の大工業が労働力を農村からうけとる可能性を失うこと，第 2 に,コルホーズ員の大きな部分が農 業生産からひきはなされ, 農業がコルホーズ生産のなかで後景に退いてしまうであろうこと，てれであ った(『ソ連邦共産党史の諸問題』, 1982 年, 第 8 号, 53 頁)。スターリンのての発言は, コル ホーズを農業生産組織として「固定」するとともに，他方でそれを国営工業向けの労働力調達の源泉と するとい51930 年代ソヴェトの構造を簡潔に語ったものであり，ててに農民の一種の「身分化」の 思想を読みとるととも不可能ではない。

コルホーズの工業的活動に対する「禁止」は1930 年代前半においてはデ・ファクトなものであり, いかなる立法も存在しない。その事実は，1938 年から翌年にかけて立法化された。政策的変化の兆 候はやっとフルシチョフ後の第 23 回党大会以降にあらわれたが, 農村の小規模な工業経営が現在のソ ヴェトにおいて活発化しはじめたという情報を，いまのとてろ私はまだ受けとっていない。その意味に おいて，第 1 次 5 か年計画およびそれに先立つ時期を研究するてとはすぐれて現代的な意味をもってい るのであり，20 年代末から 30 年代初頭にかけての工業化と集団化が現代ソヴェトの歴史的原型をつ くりだしたということは, とのテーマに関してもいえるととであろう。 